University of Nebraska - Lincoln DigitalCommons@University of Nebraska - Lincoln

2006

\title{
Moisture-Induced Delayed Spallation and Interfacial Hydrogen Embrittlement of Alumina Scales
}

James L. Smialek Ph.D.

NASA Glenn Research Center, james.1.smialek@nasa.gov

Follow this and additional works at: http://digitalcommons.unl.edu/nasapub

Smialek, James L. Ph.D., "Moisture-Induced Delayed Spallation and Interfacial Hydrogen Embrittlement of Alumina Scales" (2006). NASA Publications. 225.

http://digitalcommons.unl.edu/nasapub/225

This Article is brought to you for free and open access by the National Aeronautics and Space Administration at DigitalCommons@University of Nebraska - Lincoln. It has been accepted for inclusion in NASA Publications by an authorized administrator of DigitalCommons@University of Nebraska - Lincoln. 


\title{
Moisture-Induced Delayed Spallation and Interfacial Hydrogen Embrittlement of Alumina Scales
}

\author{
James L. Smialek
}

While interfacial sulfur is the primary chemical factor affecting $\mathrm{Al}_{2} \mathrm{O}_{3}$ scale adhesion, moisture-induced delayed spallation appears as a secondary, but impressive, mechanistic detail. Similarities with bulk metallic phenomena suggest that hydrogen embrittlement from ambient humidity, resulting from the reaction $\mathrm{Al}_{\text {alloy }}+3\left(\mathrm{H}_{2} \mathrm{O}\right)_{\text {air }}=\mathrm{Al}(\mathrm{OH})_{3}^{-}$ $+3 \mathrm{H}^{+}$may be the operative mechanism. This proposal wastested on pre-oxidized René $N 5$ by standard cathodic hydrogen charging in $1 \mathrm{~N}_{2} \mathrm{SO}_{4}$, as monitored by weight change, induced current, and microstructure. Cathodic polarization at $-2.0 \mathrm{~V}$ abruptly stripped mature $\mathrm{Al}_{2} \mathrm{O}_{3}$ scales at the oxide-metal interface. Anodic polarization at $+2.0 \mathrm{~V}$, however, produced alloydissolution. Finally, with no applied voltage, the acid electrolyte produced neither scale spallation nor alloy dissolution. Thus, hydrogen charging was detrimental to alumina scale adhesion. Moisture-induced interfacial hydrogen embrittlement is concluded to be the cause of delayed scale spallation and desktop thermal barrier coating failures.

\section{INTRODUCTION}

High-temperature turbine materials rely on the formation of protective scales for durable operation. Specifically, single-crystal nickel-based superalloy

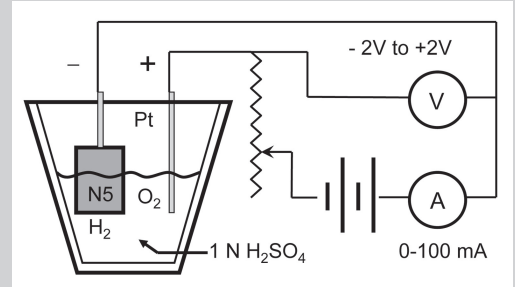

Figure 1. Aschematic of the electrochemical hydrogen charging cell. airfoils are usually coated with aluminide conversion coatings of $\mathrm{Ni}(\mathrm{Pt}) \mathrm{Al}$ or with overlay $\mathrm{Ni}(\mathrm{Co}) \mathrm{CrAlY}$ coatings, both producing slow-growing, adherent $\alpha-\mathrm{Al}_{2} \mathrm{O}_{3}$ scales. These coatings may also be used as bond coatings beneath yttria-stabilized zirconia (YSZ) thermal barrier coatings (TBCs), whose cyclic life depends on maintaining these same beneficial properties of the thermally grown oxide (TGO) interface layer. Cyclic oxidation tests are often used to characterize oxidative stability of both the bond coat class of materials alone as well as the TBC system as a whole. It is well recognized that the primary driving force for scale and TBC spallation is their low thermal expansion, compared to the metal substrate, and the high biaxial compressive thermal mismatch stress and strain energy that results on cooldown. Scale adhesion is maximized chemically with low-sulfur ( $<1 \mathrm{ppmw})$ coatings and alloys, as well as platinum additions and reactive element dopants (e.g., $\leq 0.1 \%$ yttrium, hafnium, and zirconium). However, a secondary factor affecting failure of the scale or TBC may be moisture in the ambient air after cooldown, especially in the case of damaged or marginally adherent scales.

Secondary, moisture-induced delayed spallation (MIDS) is the phenomenon addressed by this study. Laboratory experience on this topic has been recently summarized in detail, ${ }^{1}$ along with critical experiments by numerous other investigations. Basically, the susceptibility of $\alpha-\mathrm{Al}_{2} \mathrm{O}_{3}$ scales to this phenomenon is enabled by marginal sulfur levels, exposed interfaces from spallation or through cracks, or high strain energies that result when the scales grow thick.

See the sidebar on pages 32-33 for details on moisture-induced delayed spallation.

\section{HYDROGEN \\ EMBRITTLEMENT \\ EXPERIMENT}

To test whether hydrogen embrittlement controls MIDS in ambient air or water immersion, a standard electrolytic procedure was used to charge pre-oxidized René N5 samples with hydrogen. The expectation was that an excess of hydrogen would accentuate interfacial spalling for a damaged, highly stressed mature scale. From the literature, electrolytic hydrogen charging is often accomplished in sulfur, phosphorous, or arsenic poisoned $\mathrm{H}_{2} \mathrm{SO}_{4}$, at currents $\leq 150 \mathrm{~mA} / \mathrm{cm}^{2}$ and potentials $\leq-2 \mathrm{~V}$ $(\mathrm{Ag} / \mathrm{AgCl}){ }^{20,21,30}$ The simple charging cell used in these tests is shown schematically in Figure 1, using only a 0.05 $\mathrm{cm}$ platinum wire counter-electrode without a reference electrode. The working electrode consisted of $1.3 \times 2.5 \mathrm{~cm}$ N5 coupons suspended from a platinum wire, submerged about halfway into the $100 \mathrm{~mL}$ solution. The bottom edge of the coupon was sanded to insure a conductive path to the oxide-metal interface. A constant-voltage power supply was used to apply a potential, while cell current was measured using a precision

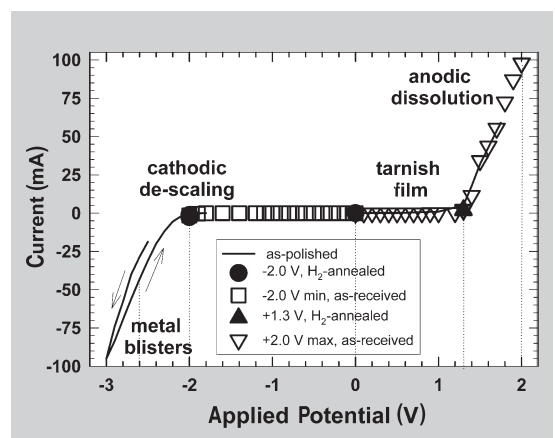

Figure 2. The current response for $0.1 \mathrm{~V}$ steps in applied voltage (voltammogram): for bare René N5 (line) and pre-oxidized René N5 (symbols). 
potentiometer across a low-resistance load of $1 \mathrm{ohm}$.

Duplicate N5 samples were exposed to a constant positive or negative potential and monitored for response by current, weight change, and surface macro- and microstructure. The potentials were chosen based on the general response of a bare control sample. Generally, the low current knee of the current-voltage response curve was used to maximize charge transfer while minimizing electrolysis and gas formation. Scanning-electron microscopy (SEM) with energy-dispersive spectroscopy (EDS) was performed on both cathodically $(-)$ and anodically (+) treated oxidized samples as well as on a bare sample after both anodic and cathodic exposure. Secondary electron imaging (SEI) and backscatter-electron imaging (BSE) were used to accentuate morphological details and chemical contrast, respectively.

The René N5 samples and pertinent oxidation, immersion, and electrochemical treatment data are summarized in Table I. In the table, $\mathrm{H}_{2}$ condition refers to hydrogen annealing in $5 \% \mathrm{H}_{2} / \mathrm{Ar}$ at $1,250^{\circ} \mathrm{C}$ for $100 \mathrm{~h}$. Yttrium and sulfur content was determined by glow charge mass spectrometry. Net weight change is after 1,0001 -h oxidation cycles at $1,150^{\circ} \mathrm{C}$, and $\mathrm{H}_{2} \mathrm{O}$ weight is the additional

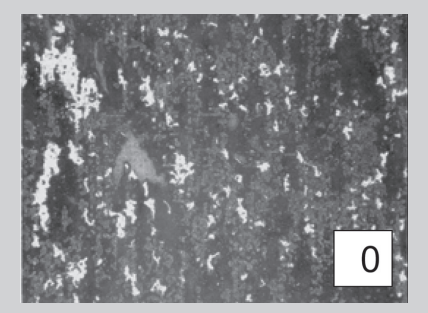

a

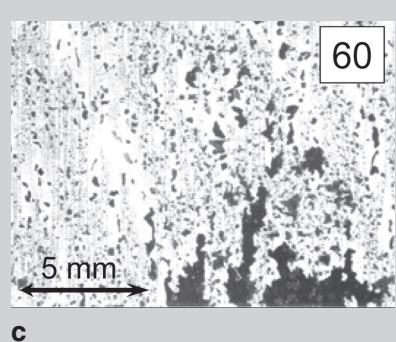

c

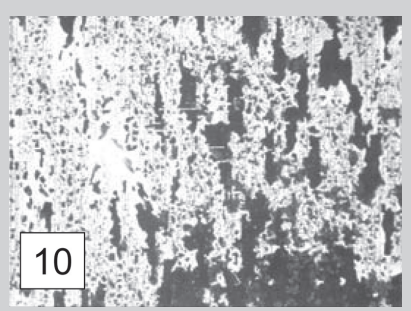

b

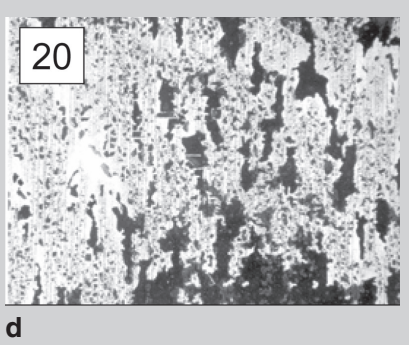

Figure 4. Macrographs obtained after (a) 0 min., (b) $10 \mathrm{~min} .$, (c) $60 \mathrm{~min}$., and (d) $20 \mathrm{~min}$. of cathodic charging at $-2.0 \mathrm{~V}$ showing rapid interfacial de-scaling of René N5+80Y (pre-oxidized at $1,150^{\circ} \mathrm{C}$ for $1,000 \mathrm{~h}$ ). spallation due to immersion. Current response and weight losses are listed for about $1 \mathrm{~h}$ at the applied voltage in $1 \mathrm{~N} \mathrm{H}_{2} \mathrm{SO}_{4}$, with data for selected secondary treatments. The hydrogen-annealed samples (48-1, 67-1) formed more adherent scales (even though no desulfurization occurred). Anodic polarization (48-1,2) resulted in little current or weight loss at +1.3 $\mathrm{V}$, increasing dramatically at $+2.0 \mathrm{~V}$ due to alloy dissolution. Immersion in $\mathrm{H}_{2} \mathrm{SO}_{4}$ at $0.0 \mathrm{~V}$ resulted in very little change (67-1), but subsequent cathodic polarization at $-2.0 \mathrm{~V}$ produced substantial 1.3-to-2.7 $\mathrm{mg} / \mathrm{cm}^{2}$ losses at

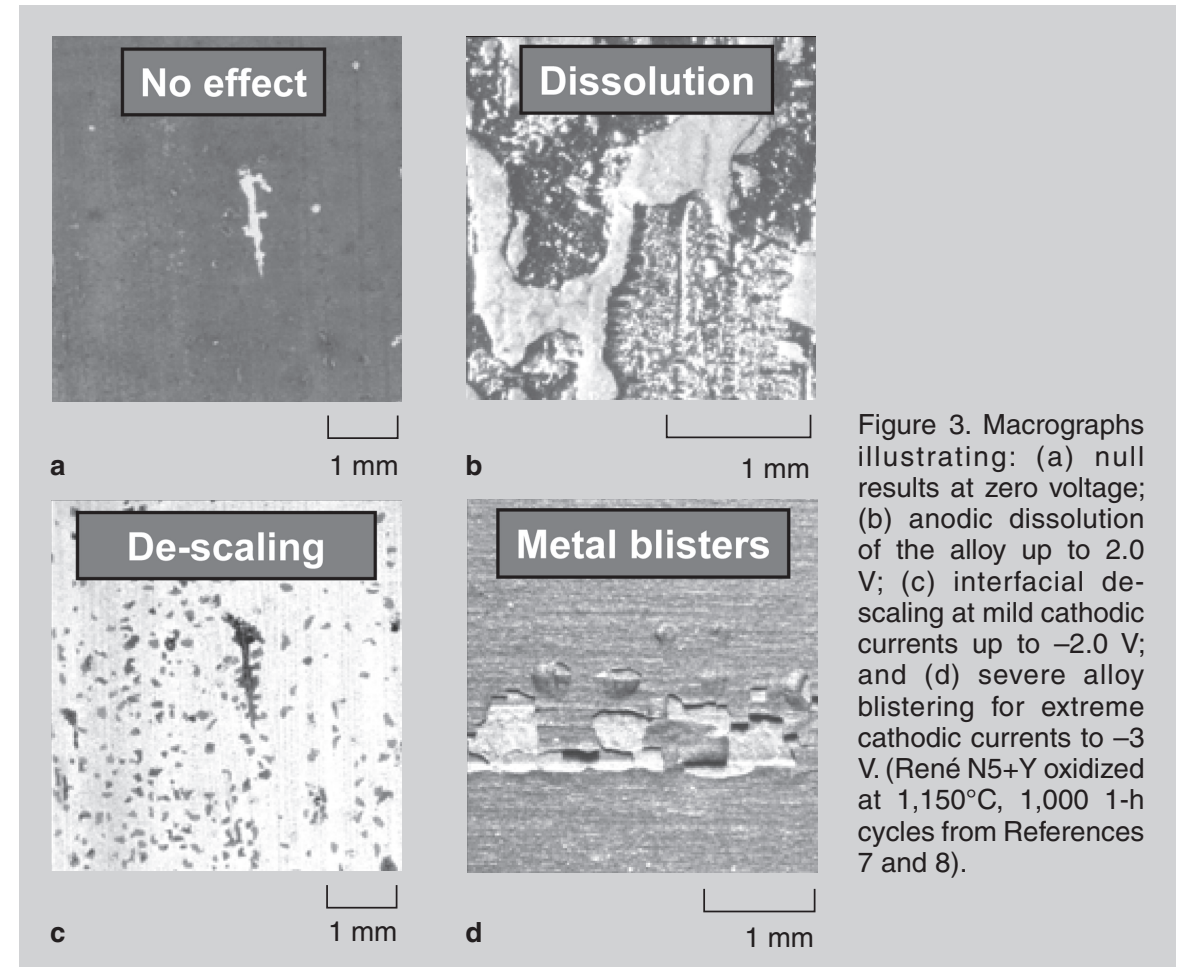

currents less than $-0.5 \mathrm{~mA}$, primarily due to de-scaling (67-1,2). Finally, a non-oxidized sample (N5-0) lost 4 $\mathrm{mg} / \mathrm{cm}^{2}$ by anodic dissolution at +1.8 $\mathrm{V}$, followed by $0.5 \mathrm{mg} / \mathrm{cm}^{2}$ by cathodic hydrogen overcharging and blistering at $-3.0 \mathrm{~V}$.

\section{General Response}

Rapid decay was observed in the current response curves for both cathodic $(-2.0 \mathrm{~V})$ and anodic $(+2.0 \mathrm{~V})$ polarizations. ${ }^{1}$ Therefore, to map the current/voltage characteristic response (cf. voltammogram), the current after a standard 1-2 min. decay period was plotted, as were longer-term exposures at a constant voltage. The solid line in Figure 2 plots behavior of the non-oxidized, as-polished N5 coupon, whereas the data points show the behavior of the coupons pre-oxidized for 1,000 1 -h cycles at $1,150^{\circ} \mathrm{C}$. Samples labeled " $\mathrm{H}_{2}$ " had been prepared by hydrogen annealing in $5 \% \mathrm{H}_{2} / \mathrm{Ar}$ at $1,150^{\circ} \mathrm{C}$ for $100 \mathrm{~h}$, whereas samples designated "A.R." had been oxidized in the asreceived condition. Severe bubbling at the working electrodes and excessive (100 mA) currents were noted above $+1.3 \mathrm{~V}$ or below $-2.0 \mathrm{~V}$. This indicated substantial overvoltages for the generation of $\mathrm{O}_{2}$ or $\mathrm{H}_{2}$ gas, respectively, at the working sample electrode. This compares with similar transitions, at +1.0 and $-0.5 \mathrm{~V}$, respectively, for bare N5 calibrated against an $\mathrm{Ag} / \mathrm{AgCl}$ standard electrode $^{1}$ (where $\mathrm{E}_{\mathrm{o}, \mathrm{Ag} / \mathrm{AgCl}}=+0.197 \mathrm{~V}$ on the hydrogen scale. Between these extremes the currents were much smaller 
$(<2.5 \mathrm{~mA})$ and the processes were much more controlled. The overall response is illustrated by the macrographs in Figure 3. At $0.0 \mathrm{~V}$, holding for $1 \mathrm{~h}$ produced no additional loss of material from the original water immersion treatment (Figure $3 \mathrm{a}$ ), whereas after the same amount of time at $-2.0 \mathrm{~V}$, nearly the entire scale was stripped from the sample (i.e., cathodic de-scaling) (Figure 3c). This sample (67-1) had been hydrogen annealed and exhibited excellent scale adhesion for 1,0001 -h cycles at $1,150^{\circ} \mathrm{C}$. The second sample (67-2) subjected to a cathodic $-2.0 \mathrm{~V}$ potential is shown in Figure 4 to be seriously stripped of scale within the first $10 \mathrm{~min}$., followed by lesser amounts at $20 \mathrm{~min}$. and $60 \mathrm{~min}$. In general, cathodic de-scaling initiated adjacent to interfaces previously exposed from spallation or at the sanded bottom edge of the sample. The non-oxidized, as-polished sample (N5-0), polarized at $-3.0 \mathrm{~V}$, exhibited blistering and cracking of the surface due to excessive hydrogen charging (Figure 3d). While excessive bubbling and high $95 \mathrm{~mA}$ currents were associated with $\mathrm{H}_{2}$ formation at $-3.0 \mathrm{~V}$, little bubbling was produced during cathodic de-scaling at low $<1 \mathrm{~mA}$ currents at $-2.0 \mathrm{~V}$. By way of contrast, reverse polarization above the knee in the voltammogram at $+2.0 \mathrm{~V}$ produced anodic dissolution and undercutting of intact oxide (48-2) (Figure $3 \mathrm{~b}$ ). ${ }^{1}$

\section{Microstructure}

Features resulting from cathodic descaling are shown in more detail in the SEM/SEI/BSE micrographs of Figure 5. The vast majority of the sample surface

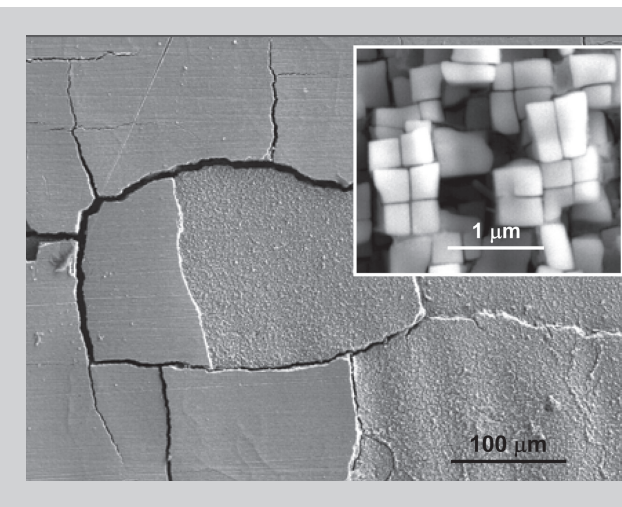

Figure 6. Structures resulting from $-3.0 \mathrm{~V}$ cathodic charging of unoxidized René $\mathrm{N} 5$ in $1 \mathrm{~N} \mathrm{H}_{2} \mathrm{SO}_{4}$, showing macrocracks, blisters, and $\gamma / \gamma^{\prime}$ interfacial disruption. was bare metal having imprints of the oxide grains (insets). Generally, only small entrained particles of $\mathrm{Al}_{2} \mathrm{O}_{3}$ scale remained, exhibiting both transgranular and intergranular fracture. Tantalum-rich particles, identified as $\mathrm{TaC}$ by $\mathrm{x}$-ray diffraction (XRD), were also observed at the exposed metal interface. Finally, extruding growths of $\mathrm{HfO}_{2}$, also identified by XRD scans, appeared above the outer surface of most intact $\mathrm{Al}_{2} \mathrm{O}_{3}$ plates. Micro-deposition of dispersed platinum particles was also observed, presumably due to platinum electrodeposition from the positive platinum wire to the negative René N5 electrode.

The cathodic hydrogen over-charging of the bare René N5+Y sample at -3.0 $\mathrm{V}$ is seen to cause surface failure with no applied stress (Figure 6). High hydrogen contents resulted in microcracking, delamination, and a disruption of the alloy integrity at $\gamma / \gamma^{\prime}$ interfaces (inset). Similar features were found on both the intact external surface as well as in the underlying layers exposed by flaking and blistering. Since this treatment produces high cathodic currents below the knee

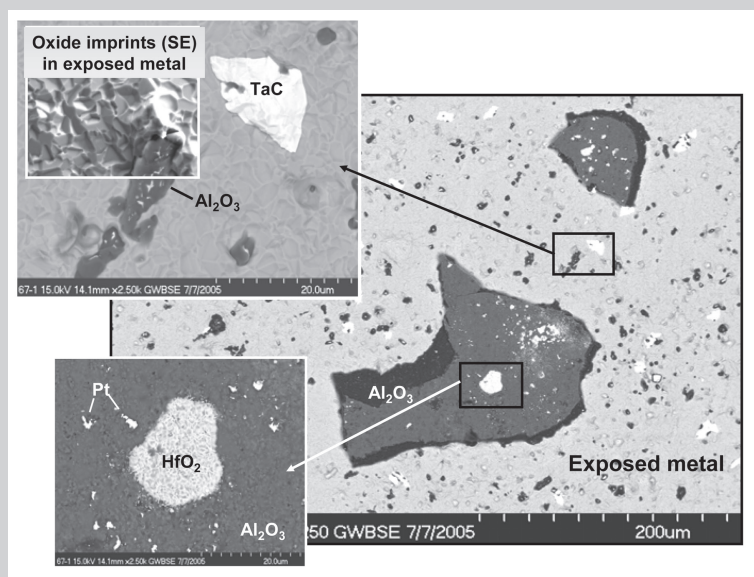

Figure 5. Montage of SEM/ BSE/SEI microstructures after cathodic de-scaling in $1 \mathrm{NH}_{2} \mathrm{SO}_{4}$ at-2.0V for $1 \mathrm{~h}$ showing: a limited amount of (dark) retained $\mathrm{Al}_{2} \mathrm{O}_{3}$ scale (mostly as dispersed particles with [light] $\mathrm{HfO}_{2}$ overgrowths and platinum particles) and major areas of spalling to (bright) bare metal, revealing oxide imprints and (white) $\mathrm{TaC}$ particles. René $\mathrm{N} 5+\mathrm{Y}$ oxidized at $1,150^{\circ} \mathrm{C}, 1,000$ 1 -h cycles. in the voltammogram, it may not reflect precisely the same mechanism producing interfacial failure at the low currents of the cathodic knee, $-2.0 \mathrm{~V}$.

\section{Weight Change}

The samples were also monitored by weight change periodically throughout the electrolytic treatments (Figure 7). Polarization at the $-2.0 \mathrm{~V}$ cathodic knee produced massive scale delamination, most evident after only $10 \mathrm{~min}$., but always at low currents $<1.0 \mathrm{~mA}$. By contrast, once the scale was removed, little further weight loss was observed. It is interesting to point out that the hydrogen-annealed sample (67-1) actually produced more weight loss than the corresponding as-received sample (67-2). This may be due to the larger original amount of intact scale available for cathodic de-scaling. The sample polarized at the $+1.3 \mathrm{~V}$ anodic knee showed very little weight loss $(<0.25$ $\left.\mathrm{mg} / \mathrm{cm}^{2}\right)$ and very low currents $(<1.0$ $\mathrm{mA})$. Anodic polarization at $+2.0 \mathrm{~V}$, however, produced an increasing severe weight loss of $>8 \mathrm{mg} / \mathrm{cm}^{2}$ with high currents of $110 \mathrm{~mA}$. Additional weight loss occurred by removing a sooty corrosion product by ultrasonic cleaning.

The differences between anodic and cathodic weight change behavior can be further accentuated by mapping the rate of weight loss versus imposed current. For anodic electrochemical dissolution, weight loss rate was reasonably commensurate with current, performed at +1.3 or ramped to $+2.0 \mathrm{~V}$ (Figure 8). In contrast, the cathodic tests performed at $-2.0 \mathrm{~V}$ produced high initial weight losses at low currents, subsiding completely when no more scale was left to spall (Figures 3-5). Thus, discontinuous cathodic de-scaling is again distinguished from continuous anodic dissolution. 
Table I. Weight Changes for Cyclic Oxidation, Water Immersion, and Anodic and Cathodic $\mathrm{H}_{2} \mathrm{SO}_{4}$ Polarization Treatments of As-Received (A.R.) and Hydrogen Annealed $\left(\mathrm{H}_{2}\right)$ René N5

\begin{tabular}{|c|c|c|c|c|c|c|c|c|c|c|}
\hline Sample & Condition & $\begin{array}{c}\text { Y } \\
\text { ppmw }\end{array}$ & $\begin{array}{c}\text { S } \\
\text { ppms }\end{array}$ & $\begin{array}{l}\Delta \mathbf{W}_{1000 \mathrm{~h}} \\
\mathrm{mg} / \mathrm{cm}^{2}\end{array}$ & $\begin{array}{c}\Delta W_{\mathrm{H} 2 \mathrm{O}} \\
\mathrm{mg} / \mathrm{cm}^{2}\end{array}$ & $\begin{array}{c}\text { V } \\
\text { volts }\end{array}$ & $\underset{\mathbf{m A}}{\mathbf{I}}$ & $\begin{array}{c}\Delta W_{1} \\
\mathbf{m g} / \mathrm{cm}^{2}\end{array}$ & $\begin{array}{c}\Delta W_{1+2} \\
\mathbf{m g} / \mathbf{c m}^{2}\end{array}$ & Second Treatment \\
\hline \multicolumn{11}{|l|}{ Anodic } \\
\hline $48-1$ & $\mathrm{H}_{2}$ & 20 & 7.0 & 0.638 & -0.107 & 1.3 & 0.70 & -0.258 & -0.347 & 2 min. @-2.0V \\
\hline $48-2$ & A.R. & 20 & 5.2 & -0.972 & -0.415 & 2.0 & 112.0 & -5.462 & -8.317 & ultrasonic de-sooting \\
\hline \multicolumn{11}{|l|}{ Cathodic } \\
\hline $67-1$ & $\mathrm{H}_{2}$ & 80 & 5.5 & 0.932 & -0.068 & $\begin{array}{c}0.0 \\
-2.0\end{array}$ & $\begin{array}{c}0.00 \\
-0.37\end{array}$ & $\begin{array}{l}-0.041 \\
-2.730\end{array}$ & - & - \\
\hline $67-2$ & A.R. & 80 & 4.9 & -1.162 & -0.122 & -2.0 & -0.43 & -1.315 & - & - \\
\hline \multicolumn{11}{|l|}{ Both } \\
\hline N5-0 & A.R. & 0.3 & 2.5 & $* * *$ & $* * *$ & $\begin{array}{c}1.8 \\
-3.0\end{array}$ & $\begin{array}{c}3.1 \\
-95\end{array}$ & $\begin{array}{l}-3.983 \\
-0.541\end{array}$ & - & - \\
\hline
\end{tabular}

\section{MOISTURE-INDUCED DELAYED SPALLATION}

\section{Observations}

In the earliest demonstration of moisture-induced delayed spallation (MIDS), an undoped $\mathrm{Ni}-15 \mathrm{Cr}-13 \mathrm{Al}$ (wt.\%) alloy was repeatedly oxidized at $1,120^{\circ} \mathrm{C}$, weighed, wet polished lightly, then reoxidized to remove segregated sulfur impurities. ${ }^{2}$ After the scales first became adherent, they were found to be completely stripped by water immersion. Eventually, enough sulfur was removed to allow the scale to remain adherent even when exposed to water. In subsequent studies of sulfur effects, the authors therefore adopted procedures of exposure to hot moist breath or water immersion. This often resulted in remarkable displays of water-induced spallation for single-crystal superalloys, such as PWA 1480, PWA 1484, René 142 , and René N5, ${ }^{3-9}$ as summarized in Reference 1. The latter alloys are protected by an inner layer of $\alpha-\mathrm{Al}_{2} \mathrm{O}_{3}$. In general, higher sulfur contents and longer oxidation treatments produced greater sensitivity to moisture-induced spallation, while desulfurization produced immunity to moisture effects.

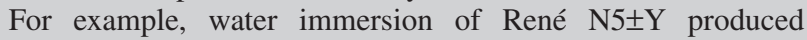
substantial interfacial scale spallation for otherwise quite protective scales, grown at $1,150^{\circ} \mathrm{C}$ for 5001 -h cycles. ${ }^{4,5,7}$ For a duplicate set of samples, hydrogen annealing in $5 \% \mathrm{H} / \mathrm{Ar}$ at $1,250^{\circ} \mathrm{C}$ for $100 \mathrm{~h}$ has been shown to essentially eliminate this moisture effect. (Here bulk desulfurization, from 5 down to $<0.1$ ppmw sulfur, occurred only for the yttrium-free alloy, whereas decarburization, from 500 down to 100 ppmw carbon, occurred for all samples). This effect is illustrated visually in the macrographs of Figure A. Furthermore, continuous monitoring by acoustic emission (AE) substantiated the large benefit of hydrogen annealing on the elimination of

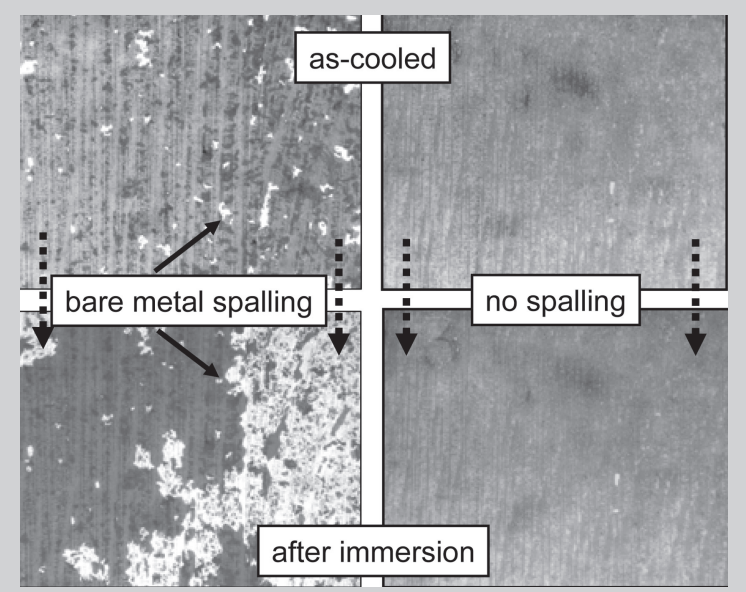

as-received

$\mathrm{H}_{2}$-annealed

Figure A. The effect of water immersion on the amount of additional spallation for René N5+100Y after 5001 -h cycles at $1,150^{\circ} \mathrm{C}$ : appreciable for as-received samples and minimal for hydrogenannealed $\left(\mathrm{H}_{2}\right)$ in $5 \% \mathrm{H}_{2} / \mathrm{Ar}$ at $1,250^{\circ} \mathrm{C}$ for $100 \mathrm{~h}$ (from References 7 and 8). acoustic events. Here moisture-induced spallation was shown for long durations up to several hours, with multiple events proceeding in consecutive, near-instantaneous bursts. ${ }^{8}$

Along similar lines, it is often noted in cyclic furnace testing that catastrophic failure of a thermal barrier coating (TBC) does not immediately occur on cooldown, as expected for just attaining the maximum thermal expansion mismatch stresses. Rather, an incubation period of minutes, hours, or days is experienced before failure, which may itself be of short duration. ${ }^{6,9}$ For example, failure of commercially applied electron-beam physical-vapor deposition (EB-PVD) modified yttria-stabilized zirconia (YSZ) coatings, with a conventional platinum-aluminide bond coat on René N5, failed well after cooldown had been completed from 720 furnace cycles at $1,135^{\circ} \mathrm{C}$ (Figure Ba). ${ }^{1}$ The failure locus of one sample (560 cycles) was examined by x-ray diffraction (XRD) and scanning-electron microscopy/energy dispersive spectrometry (SEM/EDS) of the exposed sample surface (Figure $\mathrm{Bb}$ ). This revealed that only dispersed YSZ features remained on the sample, attached to embedded islands of $\mathrm{Al}_{2} \mathrm{O}_{3}$. These $\mathrm{Al}_{2} \mathrm{O}_{3}$ features were scattered over the surface and entrained in depressions of a heavily convoluted, but otherwise cleanly exposed bond coat (inset). Thus the failure locus appears to occur primarily at the scale-metal interface, partly through embedded scale intrusions, but least through the YSZ itself. A similar study found a direct influence of alloy sulfur content on air-plasma sprayed (APS) TBC failure, sometimes triggered by water immersion, for PWA 1484 with no bond coat. ${ }^{6.9}$ These results reinforce the importance of moisture effects on scale-metal adhesion and TBC durability.
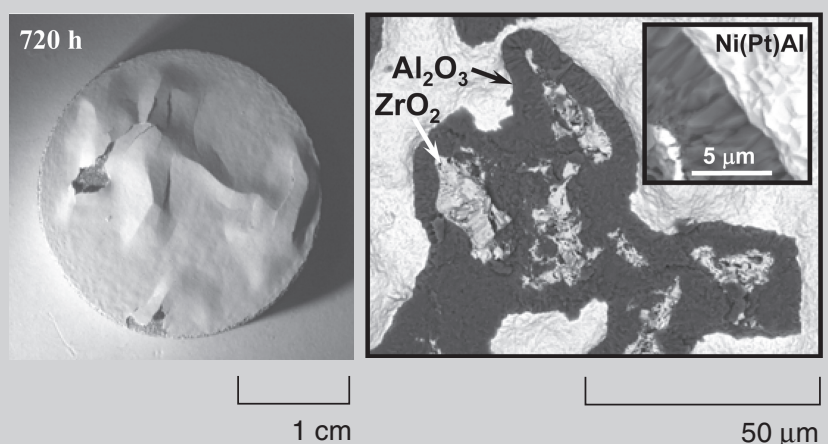

Figure B. Massive EB-PVD TBC buckling and cracking failures after cyclic oxidation (modified $\mathrm{ZrO}_{2}$ coatings, with $\mathrm{Ni}(\mathrm{Pt}) \mathrm{Al}$ bond coat on René N5, oxidized at $1,135^{\circ} \mathrm{C}$ with $45 \mathrm{~min}$. cycles). (a) Observed as delayed desktop spallation after cooldown; (b) backscatter electron images showing islands of retained scale (dark) in a sea of exposed metal (bright); dispersions of TBC (light) attached within these islands; and columnar $\mathrm{Al}_{2} \mathrm{O}_{3}$ intrusion, growing perpendicular to the $\mathrm{Ni}(\mathrm{Pt}) \mathrm{Al}$ bondcoat, with oxide grain imprints in the metal (inset). Features identified by XRD of the entire region and SEM/EDS as $\mathrm{AI}(\mathrm{O})$-rich, $\mathrm{Zr}(\mathrm{Y})$-rich, and $\mathrm{Ni}(\mathrm{Pt}, \mathrm{Al}, \mathrm{Ta}, \mathrm{Cr})$-rich areas, respectively. 
PROPOSED MODEL

Moisture effects on $\mathrm{Al}_{2} \mathrm{O}_{3}$ scale adhesion have been discussed as stress-corrosion-like mechanisms in which moisture deteriorates $\mathrm{Al}$-O bonds in the oxide, ${ }^{8,12,33}$ analogous to the corrosion fatigue crack growth observations for bulk $\mathrm{SiO}_{2}$ and $\mathrm{Al}_{2} \mathrm{O}_{3}$ ceramics. ${ }^{34-42}$ However, these tend toward more continuous controlled processes, whereas spallation tends toward instantaneous step events, as shown by the AE experiments of Reference 8. Here it had been argued that moisture provided a trigger for the loaded gun of a sulfurexpanded and weakened interface. This may be equivalent in large part to the corrosion fatigue interface toughness model, since both refer to chemical effects at the oxide metal interface. ${ }^{12}$ However, what had not been discussed is hydrogen. Rather than moisture itself, a by-product of moisture and aluminum in the alloy is now proposed as the key chemical factor.
Insofar as the electrolytic experiment here produced elemental hydrogen and caused spallation, hydrogen now appears to be a powerful agent for interfacial failure of at-risk scales.

The elementary steps in the process are shown schematically in Figure 9. From the hydrogen embrittlement literature, it can be recalled that local electrochemical cells develop at exposed oxide-metal interfaces in moist environments..$^{29} \mathrm{Here}$ $\mathrm{H}_{2} \mathrm{O}$ is adsorbed on the exposed metal

\section{Additional Supporting Studies}

These observations are corroborated or preceded by related studies. Sigler showed that moisture qualitatively increased alumina scale spallation for Fe-20Cr-5Al-X alloys (wt.\%) after oxidation at $900-1,150^{\circ} \mathrm{C}$ for $24 \mathrm{~h} .{ }^{10} \mathrm{Smith}$, Frazier, and Pregger found that lowsulfur $(0.036 \mathrm{ppmw})$ René $\mathrm{N} 6$, oxidized at $1,150^{\circ} \mathrm{C}$ for $24 \mathrm{~h}$, formed adherent scales in either dry or moist air, with resistance to spallation in bend tests. ${ }^{11}$ In contrast, a high sulfur (4.3 ppmw) alloy spalled in humid environments, whether oxidized in moist air or just transferred to ambient humidity after cooldown from a dry gas mixture. Humid conditions also produced increased spallation for this alloy in bend tests compared to a vacuum environment.

Janakiraman, Maris-Sida, Onal Hance, Meier, and Pettit conducted extensive studies of the effects of moisture on the 700 $1,100^{\circ} \mathrm{C}$ cyclic oxidation of alumina-forming single-crystal superalloys (PWA 1480, 1484, CMSX-4) and coatings $(\mathrm{Ni}(\mathrm{Pt}) \mathrm{Al}$, MCrAlY $)$ in wet $\left(\mathrm{p}_{\text {н20 }}=0.01 \mathrm{MPa}\right)$ or dry $\left(\mathrm{p}_{\text {н2о }}=6 \times 10^{-6} \mathrm{MPa}\right)$ air. ${ }^{12-14}$ At $1,100^{\circ} \mathrm{C}$, superalloys with $>3 \mathrm{ppmw}$ sulfur showed substantially more weight loss in moist air, with no increase in oxidation rate. In contrast, samples melt-desulfurized or hydrogenannealed to $<1 \mathrm{ppmw}$ sulfur were virtually immune to the moisture effect for 3,000 h. Water droplet tests also produced spallation for a high-sulfur alloy, diminishing as continued sulfur purging was accomplished by repeated oxidation/polishing cycles. These and similar studies point out the potential of also altering transient oxides when oxidation is performed in moist environments. ${ }^{15}$

Tolpygo, Sergo, and Clarke used photoluminescence piezospectroscopy to characterize the scale stress state and buckling for oxidized $\mathrm{FeCrAlZr}^{16}$ and for an EB-PVD TBC with an NiCoCrAlY bond coat on PWA $1484 .{ }^{17}$ Both studies found that cracks and buckle progression proceeded over days and attributed such subcritical crack growth to ambient moisture effects. Renusch, Eschler, and Schutze have recently documented long-term AE activity cracking in the alumina scale after cooldown for an oxidized APS TBC/NiCrAlY bond-coated IN738 samples. ${ }^{18}$ Also, samples pre-oxidized in dry and wet air were fractured in-situ in high vacuum to expose the oxide-metal interface, where hydrogen was found by proton-induced gamma emission techniques. ${ }^{19}$

It is also apparent from the literature that moist environments cause similar intriguing detrimental effects on the ductility of

Table A. Features of Hydrogen Embrittlement in Bulk Intermetallics Analogous to Those Observed $(\sqrt{ })$ or Proposed (?) for Interfacial Embrittlement of Alumina Scales

\begin{tabular}{|c|c|c|}
\hline $\begin{array}{l}\text { Common } \\
\text { Aspects }\end{array}$ & $\begin{array}{l}\text { Alloy Fracture } \\
(1951-1989)\end{array}$ & $\begin{array}{l}\text { Scale Spallation } \\
(1985-2005)\end{array}$ \\
\hline$\overline{\text { Sulfur Segregation: }}$ & $\overline{\text { Intergranular embrittlement }}$ & $\checkmark$ Interfacial weakening \\
\hline Moisture Effects: & Intergranular and cleavage & $\checkmark$ Interfacial weakening \\
\hline $\begin{array}{l}\text { Hydrogen Diffusion, } \\
\text { Tensile Stress: }\end{array}$ & $\begin{array}{l}\text { Delayed room temp. failure, } \\
\text { Intermittent crack growth }\end{array}$ & $\begin{array}{l}\checkmark \text { Delayed room temp. failure, } \\
\checkmark \text { Intermittent spallation }\end{array}$ \\
\hline Theoretical Strength: & $\mathrm{H}, \mathrm{S}$ decrease $\mathrm{M}-\mathrm{M}$ bond & $\checkmark \mathrm{H}, \mathrm{S}$ decrease $\mathrm{M}-\mathrm{Al}_{2} \mathrm{O}_{3}$ bond \\
\hline $\mathrm{H}+\mathrm{S}$ Segregation: & Negative synergy & ? Negative synergy \\
\hline Cathodic Charging: & H-embrittlement & ? Interfacial de-scaling \\
\hline
\end{tabular}

intermetallic compounds, such as $\mathrm{Ni}_{3} \mathrm{Al}$ and $\mathrm{FeAl}$, eventually identified as hydrogen embrittlement. ${ }^{20-25}$ Hydrogen embrittlement of single-crystal superalloys has also been identified. ${ }^{26,27}$ Classic hydrogen embrittlement exhibits many features in common with delayed scale spallation as listed in Table A: an interfacial aspect, an intermittent nature depending on hydrogen diffusion ahead of the crack tip, the necessity of a tensile stress state, a negative synergy with segregated sulfur, and a reduction in the theoretical bond strength..$^{28-30}$

Based on the compelling parallels, it is postulated that the same underlying phenomenon, hydrogen embrittlement, also controls MIDS in ambient air or water immersion. This hypothesis was first presented, along with much of the forgoing circumstantial evidence and preliminary results, at a TMS-ASM symposium on water vapor effects on the high-temperature oxidation of materials, and more recently elaborated at the TMS-ASM symposium on superalloys and coatings for high-temperature applications..$^{31,32}$

\section{Intergranular Hydrogen Embrittlement}

Intergranular hydrogen embrittlement is a classic topic of interest for high-strength steels, nickel, titanium, and aluminum alloys. Moisture in the ambient air can, in some cases (e.g., intermetallic compounds), be the source of hydrogen-causing embrittlement, in contrast to ductile behavior in dry oxygen or vacuum. The situation for $\mathrm{Al}_{2} \mathrm{O}_{3}$ spallation caused by moisture and water immersion is consistent with this phenomenon.

Slow strain-rate sensitivity and intermittent crack growth, observed in many hydrogen embrittlement studies, are based on the time needed to diffuse hydrogen ahead of the crack tip. Room temperature or slightly above maximizes embrittlement effects due to sufficiently fast hydrogen diffusion at this temperature. (However, at elevated temperature, the diffusion becomes so fast that the hydrogen escapes from the material, as it would for hydrogen annealing above $1,100^{\circ} \mathrm{C}$ ). Delayed and intermittent scale spallation is reminiscent of such phenomena. A state of triaxial tension is needed to attract and hold hydrogen at high enough levels to cause embrittlement in metals. An analogous condition of biaxial tension is produced at the metal side of the oxide-metal interface because of thermal expansion mismatch and compressive growth in the scale.

Many theoretical studies of sulfur and hydrogen effects on metal-metal and $\mathrm{Al}_{2} \mathrm{O}_{3}$-metal interfaces strongly suggest that both elements will cause interfacial weakening. For metal embrittlement, a negative synergy has been observed, where a sulfur-contaminated-interface may be necessary to produce serious hydrogen effects. Indeed, the susceptibility of scales to MIDS increases with alloy sulfur content and presumably with interfacial contamination. It remains to be seen whether hydrogen also causes scale spallation. 
and dissociates to $(\mathrm{OH})^{-}$and $\mathrm{H}^{+}$. Anodic oxidation of aluminum from the alloy to $\mathrm{Al}^{+3}$ occurs at active exposed metal sites, resulting in $\mathrm{Al}(\mathrm{OH})_{3}\left(\mathrm{or} \mathrm{Al}_{2} \mathrm{O}_{3} \cdot \mathrm{nH}_{2} \mathrm{O}\right) \cdot{ }^{20,21}$ (A similar chemical reaction has been documented for the reaction of water and activated aluminum powders, forming $\mathrm{Al}(\mathrm{OH})_{3}$ bayerite and $\mathrm{H}_{2}$ gas. $\left.{ }^{43,44}\right)$ This frees $\mathrm{e}^{-}$cathodically at protected (passivated) areas, attracting and reducing $\mathrm{H}^{+}$. Hydrogen then diffuses interstitially under the scale, attracted to the tensile environment. At this juncture, mechanical disruption of the scale by gaseous $\mathrm{H}_{2}$ appears less likely at the low currents associated with de-scaling and no bubble formation.

The underlying metal is also under biaxial tensile strain, producing an attraction for interstitial hydrogen, analogous to hydrogen embrittlement in regions of triaxial tension ahead of the crack tip in bulk alloys. Any segregated impurities, primarily sulfur in this case, may serve as further synergistic interfacial embrittling agents. ${ }^{30}$ Sulfur is also known to retard the recombination of $\mathrm{H}^{+}$and its innocuous escape as $\mathrm{H}_{2}$ gas. It is therefore used as a poison in electrolytic hydrogen

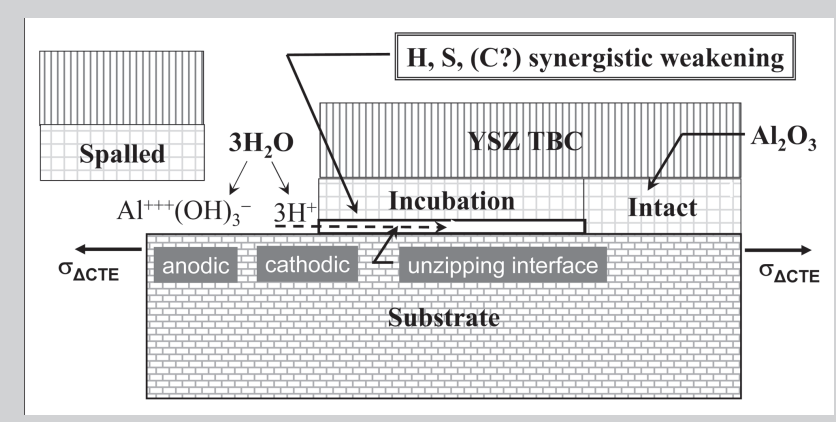

Figure 9. A schematic of moisture-induced hydrogen embrittlement mechanism for delayed failure of $\mathrm{Al}_{2} \mathrm{O}_{3}$ scales and desktop TBC spallation. A damaged $\mathrm{Al}_{2} \mathrm{O}_{3}$ scale exposes a weakened and stressed oxide-metal interface to a moist environment; local electrochemical cells produce $(\mathrm{OH})^{-}$to react with aluminum, leaving $(\mathrm{H})^{+}$to diffuse into the interface. Eventually interfacial $\mathrm{H}(+\mathrm{S})$ embrittlement allows spallation to occur.

\section{charging.}

Scale segments autocatalytically debond when the hydrogen concentration reaches a critical limit, reducing the interface toughness to where it can be overcome by the stored strain energy in the scale. This feature derives from the observation that scales directionally "unzip" as humid air is allowed localized access to an exposed interface, analogous to the often-discontinuous crack growth process documented for classic hydrogen embrittlement. ${ }^{28}$ It is also proposed that

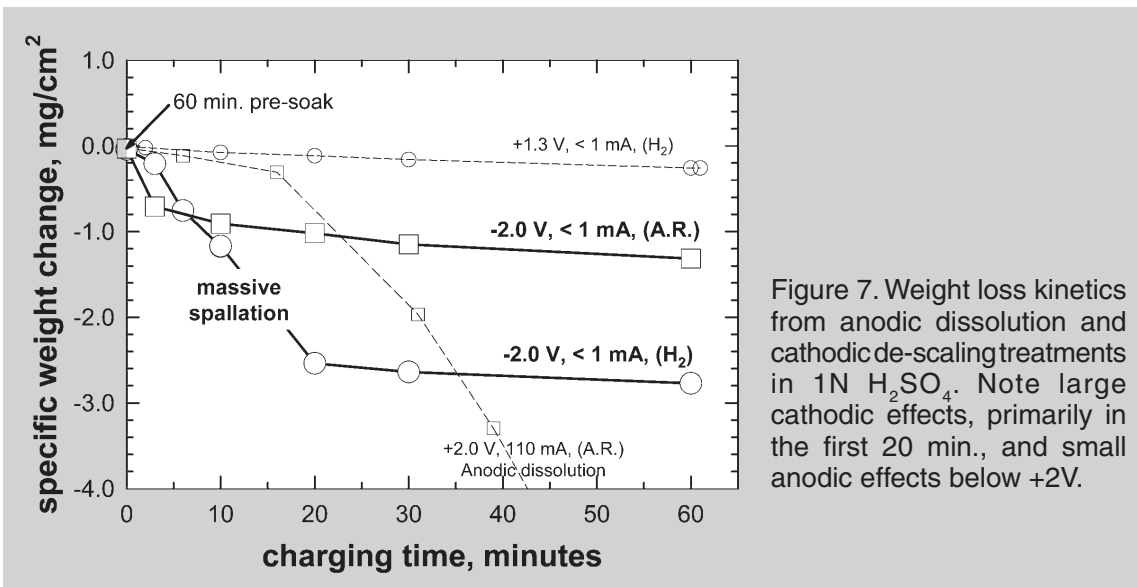

Figure 8 . The average rate of weight loss correlated with imposed current for polarization exposures in $1 \mathrm{~N} \mathrm{H}_{2} \mathrm{SO}_{4}$ : increasing with increasingly higher anodic current, as contrasted with discontinuous, initial spikes at comparatively low cathodic currents. (René $\mathrm{N} 5+\mathrm{Y}$ oxidized at $1,150^{\circ} \mathrm{C}, 1,000$ 1-h cycles)

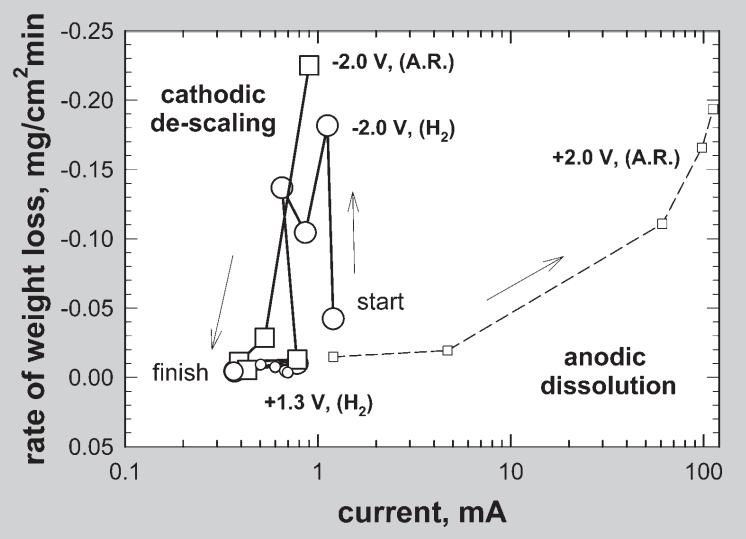

the scale cracking and spallation process itself is near instantaneous $\left(\tau_{\text {spall }}\right)$, previously requiring some finite time for water dissociation and hydrogen diffusion $\left(\tau_{\text {incubate } 2}\right)$, relegating the remaining scale to much longer residence times $\left(\tau_{\text {intact }}\right)$ or indefinite immunity. ${ }^{8}$

\section{CONCLUSIONS}

Thermal expansion mismatch and interfacial sulfur activity remain the major factors defining primary $\mathrm{Al}_{2} \mathrm{O}_{3}$ scale spallation. However, MIDS is a secondary, but often dramatic, illustration of an additional mechanistic detail. Here interfacial hydrogen embrittlement resulting from ambient air was presented as the causative factor. Standard electrochemical hydrogen-charging techniques were successfully used to abruptly strip a mature $\mathrm{Al}_{2} \mathrm{O}_{3}$ scale at the oxide-metal interface. Cathodic de-scaling was accomplished at low $<1 \mathrm{~mA}$ currents, just at the $-2 \mathrm{~V}$ knee in the sigmoidal voltammogram response curve. This is in contrast to more gradual alloy anodic dissolution that occurred in direct proportion to voltage $>2 \mathrm{~V}$. Finally, with no applied voltage, $\mathrm{H}_{2} \mathrm{SO}_{4}$ alone produced no additional scale spallation or dissolution (within the precision and duration of the experiment) as monitored by weight change, induced current, or microstructure.

These experiments highlight the detrimental effects of hydrogen charging on alumina scale adhesion. The symptoms of moisture-induced scale spallation are highly analogous to moisture-induced hydrogen embrittlement mechanisms known to occur for bulk alloys containing aluminum. It is therefore reasonable that hydrogen embrittlement may also be 
the root cause of MIDS of $\mathrm{Al}_{2} \mathrm{O}_{3}$ scales and ultimately desktop spallation of TBC's.

\section{ACKNOWLEDGEMENTS}

The scanning-electron microscopy analysis by $\mathrm{Dr}$. A. Garg and $\mathrm{Ag} / \mathrm{AgCl}$ voltammetry of Dr. N. Leventis is gratefully acknowledged. Samples were provided by Dr. L. Graham (PCC) and Dr. J. Schaeffer and W. Murphy (GE-PS, $G E-A E)$. Hydrogen annealing was performed by J. Wagner and D. Humphrey. Research was supported in part by the NASA Ultra Efficient Engine Technology, Enabling Propulsion Materials, and HiTemp Programs.

\section{References}

1. J.L. Smialek, Moisture Induced Spallation and Interfacial Hydrogen Embrittlement of $\mathrm{Al}_{2} \mathrm{O}_{3}$ Scales, NASA Technical Memorandum 214030 (Washington, D.C.: NASA, 2005).

2. J. L. Smialek, "Adherent $\mathrm{Al}_{2} \mathrm{O}_{3}$ Scales Formed on Undoped NiCrAl Alloys," N.L. Peterson Mem. Symp. Proc. on Oxidation of Metals and Associated Mass Transport, ed. M.A. Dayananda, S.J. Rothman, and W.E. King (Warrendale, PA: TMS, 1987), pp. 297-313.

3. B.K. Tubbs and J.L. Smialek, "The Effect of Sulfur Removal on Scale Adhesion to PWA 1480," Corrosion and Particle Erosion of Materials at High Temperature, ed. V. Srinivasan and K. Vedula (Warrendale, PA: TMS, 1989), pp. 459-487.

4. J.L. Smialek, "Adherent Scales Produced on Uncoated Superalloys: Desulfurized René 142 and René N5," (Paper presented at the David L. Douglass Symposium on High Temperature Corrosion during the annual meeting of the Electrochemical Society, Miami Beach, FL, Oct. 9-14, 1994), paper No. 535, 833-834.

5. J.L. Smialek et al., "Effects of Hydrogen Annealing, Sulfur Segregation and Diffusion on the Cyclic Oxidation Resistance of Superalloys: A Review," Thin Solid Films, 253 (1994), p. 285-292.

6. J.L. Smialek, "Toward Optimum Scale and TBC Adhesion on Single Crystal Superalloys," High Temperature Corrosion and Materials Chemistry, volume 98-9, ed. E.J. Opila et al. (Pennington, NJ: The Electrochemical Society, 1998), pp. 211-220.

7. J.L. Smialek and B.A. Pint, "Optimizing Scale Adhesion for Single Crystal Superalloys," Mater. Sci. Forum, 369-372 (2001), pp. 459-646; also NASA TM 2000-210362.

8. J.L. Smialek and G.N. Morscher, "Delayed Alumina Scale Spallation on René N5+Y: Moisture Effects and Acoustic Emission," Materials Science and Engineering: A, 332 (1-2) (2002), pp. 11-24.

9. J.L. Smialek, "Scale Adhesion, Sulfur Content, and TBC Failure on Single Crystal Superalloys," Ceramic Engineering and Science Proceedings, 23, 4 (2002), pp. 485-495.

10. D.R. Sigler, "Adherence Behavior of Oxide Grown in Air and Synthetic Exhaust Gas on Fe-Cr-Al Alloys
Containing Strong Sulfide-Forming Elements: $\mathrm{Ca}, \mathrm{Mg}$, Y, Ce, La, Ti, Zr," Oxidation of Metals, 40 (1993), pp. 555-583.

11. M.A. Smith, W.E. Frazier, and B.A. Pregger, "Effect of Sulfur on the Cyclic Oxidation Behavior of a Single Crystalline, Nickel-Base Superalloy," Materials Science and Engineering, A203 (1995), pp. 388-398.

12. R. Janakiraman, G.H. Meier, and F.S. Pettit, "The Effect of Water Vapor on the Oxidation of Alloys that Develop Alumina Scales for Protection," Metall. and Mat. Trans., 30A (1999), pp. 2905-2913; and in Cyclic Oxidation of High Temperature Materials, vol. 27, ed. M. Schütze and W.J. Quadakkers (London: European Federation of Corrosion, IOM, 1999), pp. 38-62.

13. M.C. Maris-Sida, G.H. Meier, and F.S. Pettit, "Some Water Vapor Effects during the Oxidation of Alloys that are $\alpha-\mathrm{Al}_{2} \mathrm{O}_{3}$ Formers," Metall. Trans., 34A (2003), pp. 2609-2619.

14. K. Onal Hance, "Effects of Water Vapor on the Oxidation Behavior of Alumina and Chromia Superalloys between $700^{\circ} \mathrm{C}$ and $1000^{\circ} \mathrm{C}$ " (Ph.D. Thesis, University of Pittsburgh, 2005)

15. C. Zhou, H. Xu, and S. Gong, "Influence of Water Vapor on the Cyclic-Oxidation Behavior of a LowPressure Plasma- Sprayed NiCrAlY Coating," Oxid. Met., 62 (2004), pp. 195-206.

16.V.Sergo and D.R. Clarke, "Observation of Subcritical Spall Propagation of a Thermal Barrier Coating," J. Amer. Ceram. Soc., 81 (12) (1998), pp. 142-161.

17. V. Tolpygo and D.R. Clarke, "Spalling Failure of $\alpha$-alumina Films Grown by Oxidation: Parts I and II," Mater. Sci. Eng., A278 (2000), pp. 142-161.

18. D. Renusch, H. Eschler, and M. Schutze, "Progress in Life Time Modeling of APS-TBC," Mat. High Temp., 21 (2004), pp. 65-76.

19. H.E. Zschau et al., "Detection of Hydrogen in Hidden and Spalled Layers of Turbine Blade Coatings," Nuclear Instruments and Methods B, in press (2005).

20. A.K. Kuruvilla and N.S. Stoloff, "Hydrogen Embrittlement of $\mathrm{Ni}_{3} \mathrm{Al}+\mathrm{B}$,' Scripta Metall., 19 (1985), pp. 83-88.

21. N.S. Stoloff and D.J. Duquette, "Moisture and Hydrogen-Induced Embrittlement of Iron Aluminides," JOM, 45 (12) (1993), pp. 30-35.

22. C.T. Liu, E.H. Lee, and C.G. McKamey, "An Environmental Effect as the Major Cause for Room Temperature Embrittlement in FeAl," Scripta Metall., 23 (1989), pp. 875-880.

23. C.T. Liu, "NiAl Aluminide Alloys," Structural Intermetallics, ed. R. Darolia et al. (Warrendale, PA:TMS, 1993), pp. 365-377.

24. N.S. Stoloff, "Hydrogen and Moisture-Induced Embrittlement of Nickel and Iron Aluminides, Hydrogen Effects in Materials, ed. A.W. Thompson and N.R. Moody (Warrendale, PA: TMS, 1996), pp. 523-537.

25. C.T. Liu et al., "Ordered Intermetallic Alloys: An Assessment," Intermetallics, 5 (1997), pp. 579-596.

26. J. Gayda, R.L. Dreshfield, and T.P. Gabb, "The Effect of Porosity and $\gamma / \gamma$ Eutectic Content on the Fatigue Behavior of Hydrogen Charged PWA 1480," Scripta Met. et Mat., 25 (1991), pp. 2589-2594.

27. J. Gayda, T.P. Gabb, and R.L. Dreshfield, "The Effect of Hydrogen on the Low Cycle Fatigue Behavior of a Single Crystal Superalloy," Hydrogen Effects on Material Behavior, ed. N.R. Moody and A.W. Thompson (Warrendale, PA: TMS, 1990), pp. 591-601.

28. A.R. Troiano, "The Role of Hydrogen and Other Interstitials in the Mechanical Behavior of Metals," 34th Edward De Mille Campbell Memorial Lecture," ASM
Transactions, 52 (1960), pp. 54-80.

29. R.P. Wei and M. Gao, "Hydrogen Embrittlement and Environmentally Assisted Crack Growth," Hydrogen Effects on Material Behavior, ed. N.R. Moody and A.W. Thompson (Warrendale, PA:TMS, 1990), pp. 789-816.

30. R.H. Jones, "Hydrogen and Impurity-Induced Intergranular Crack Growth," Hydrogen Effects on Material Behavior, ed. N.R. Moody and A.W. Thompson (Warrendale, PA:TMS, 1990), pp. 817-843.

31. J.L. Smialek, "Effect of Moisture on Secondary Spallation of Alumina Scales on Y-doped René N5" (Paper presented at the 2002 TMS Annual Meeting, Water Vapor Effects on the Oxidation of High Temperature Materials Symposium, Seattle, WA, 18-22 February 2002).

32. J.L. Smialek, "Desk Top TBC Spallation and Interfacial Hydrogen Embrittlement of Alumina Scales" (Paper presented at the 2005 TMS Annual Meeting, Superalloys and Coatings for High Temperature Applications Symposium, San Francisco, CA, 13-17 February 2005). 33. J.L. Smialek, "Oxide Morphology and Spalling Model for NiAl," Metall. Trans., 9A (1978), p. 308.

34. S.M. Weiderhorn, "Moisture Assisted Crack Growth in Ceramics," Intl. J. Fract. Mech., 4 (1968), pp. 171177

35. D.M. Kotchick and R.E. Tressler, "Surface Damage and Environmental Effects on the Strain-Rate Sensitivity of the Strength of Sapphire and Silicon Carbide Filaments," J. Mat. Sci., 10 (1975), pp. 608612.

36. J.E. Ritter and J.N. Humenik, "Static and Dynamic Fatigue of Polycrystalline Alumina," J. Mat. Sci., 14 (1979), pp. 626-632.

37. M. Reece and F. Gulu, "Indentation Fatigue of High Purity Alumina in Fluid Environments," J. Amer. Ceram. Soc., 74 (1991), pp. 148-154.

38. M. Nagabhooshanam and V.R. Dunke, "Chemiomechanical Effects on Crack Propagation: Polycrystalline $\alpha-\mathrm{Al}_{2} \mathrm{O}_{3}$, J. Mat. Sci., 27 (1992), pp. 2377-2382.

39. S.M. Barinov et al., "Influence of Environment on Delayed Failure of Alumina Ceramics," J. Eur. Ceram. Soc., 18 (1998), pp. 257-263.

40. M.E. Ebrahimi, J. Chevalier, and G. Fantozzi, "Slow Crack Growth Behavior in Alumina Ceramics," J. Mater. Res., 15 (2000), pp. 142-147.

41. S.J. Cho et al., "Influence of Humidity on the Flexural Strength of Alumina," J. Eur. Ceram. Soc., 20 (2000), pp. 761-764.

42. J.J. Kruzic, R.M. Cannon, and R.O. Ritchie, "Effects of Moisture on Grain-Boundary Strength, Fracture, and Fatigue Properties of Alumina," J. Am. Ceram. Soc., 88 (2005), pp. 2236-2245.

43. Z.Y. Deng et al., "Modification of Al Particle Surfaces by $\gamma-\mathrm{Al}_{2} \mathrm{O}_{3}$ and its Effect on the Corrosion Behavior of Al," J. Am. Ceram. Soc., 88 (2005), pp. 977-979.

44. Z.Y. Deng et al., "Temperature Effect on Hydrogen Generation by the Reaction of $\gamma$-Al, $\mathrm{O}_{3}$-Modified Al Powder with Distilled Water," J. Am. Ceram. Soc., 88 (2005), pp. 2975-2977.

James L. Smialek is a senior research fellow at NASA Glenn Research Center in Cleveland, Ohio.

For more information, contact James L. Smialek, NASA Glenn Research Center, MS 106-1, Cleveland, OH 44135; (216) 433-5500; fax (216) 433-5544; email JamesL.Smialek@nasa.gov. 